\title{
FEMALE CHILD ABUSING BY TEASING: A CASE OF HUMAN RIGHTS VIOLATION IN BANGLADESH
}

\author{
Profulla C. Sarker, Ph.D \\ Professor and Vice Chancellor, Prime University, 2A/1, North East of Darussalam Road, \\ Section-1, Mirpur, Dhaka-1216, BANGLADESH. \\ (pc_sarker@yahoo.com)
}

The main purpose of this paper is to examine teasing as one form of child abuse. It seeks to examine to what extent female child teasing affects the human rights in Bangladesh, where the 48.5 percent population is female. The specific objectives are to explore rooted causes of teasing, place of occurrence of teasing, relationship between the victimized girls and the perpetrators, and the process of teasing applied by the perpetrators against the girls. 240 girls from three selected districts of acid attack prone areas of Bangladesh involved in the study. They were selected using the technique of purposive sampling. Survey, observation, FGD, use of key informants and case study methods were applied in order to collect information on this sensitive subject. Self-administered questionnaire, which was prepared to keep in view with the objectives of the study, was used to collect primary data of the survey. Teenagers' girls, 90 percent of them were victims of acid-throwing crime, and 77.9 percent of them were in V-X grade of schooling involved in the study. Ineffective law and order, lack of socialization of the perpetrators, fear to protest against perpetrators, patriarchal society, and peer group pressure was identified as causes of teasing. 26.7 percent of the respondents were teased physically, 35.9 percent were teased orally, and 23.3 percent were teased by showing gesture and posture. About 56.6 percent perpetrators were relatives; friends and neighbours of the victims. Public places, school premises, shopping centres, etc. were reported as the physical environment where the teasing takes place. The teasing comes in many forms; such as throwing rebuke related sex, pulling clothes and making barrier on the walkway. Impacts of teasing on human rights were found in terms of discontinuation of education, low performance, insecurity, stress, trauma and suicide. Initiatives to prevent teasing should include enactment of a specific law related to teasing, mass-awareness program, and moral education, and women empowerment, proper implementation of existing laws against teasing through close cooperation of community people, victims and the establishment of law enforcing agencies.

Keywords: Female, Child abusing, teasing, human rights. 


\section{INTRODUCTION}

The total number of population of Bangladesh is about 160 million. Out of the number, 48.5 percent are female (BBS, 2009). It has been observed that the number of female literacy and women employees is increasing in different sectors. However, the number is still significantly less compared to males because of gender discrimination, gender based power practice, social attitude towards women, lack of opportunities, dependency, insecurity, etc. Some unexpected social boundaries and practices have made the road rough for women, from their childhood to adulthood.

Practice of teasing is rooted at the very beginning of civilization in many societies across the globe. In many cultures, teasing is found as joking relationship in the form of humour in a constructive manner that contributes to making network relationship among the individuals for social solidarity, as well as community stability. Teasing has negative meaning that refers to public sexual harassment or street harassment to a girl by a boy and, as a result it has an adverse impact on the personal as well as social life of the individuals, especially the girls in a patriarchal society where women chastity is highly praised.

Pawluk (1989) argued that teasing varies dramatically according to the social context in which it takes place. Teasing is also directly associated with the gender issue and as result girls are the main victims of teasing. Teasing takes place in kinship network system either consanguineous or affine (Fledman and Dodge, 1987). Consanguine relationship also takes place through birth or by blood and affine by marital tie (Aziz, 1979; Nicolas, 1961).

Parents become worried to send their daughters alone to education institutions, working places and elsewhere which creates an impediment for girls' education, employment, self-depended and self-confidence. It has been found that the victims of teasing always felt insecure, stress, and trauma. In a critical case, some of them commit suicide. 
Teasing against girls is associated with their socio-economic conditions and culture (i.e., customs, believes and value system). There are no specific rules and regulations against teasing in Bangladesh. The relevant existing rules and regulations are inadequate and at the same time less effective in practice to prevent teasing against girls. Consequently, the victims of teasing are never being taken seriously by the police and legal authority (Akhter, 2013). Recently, the government of Bangladesh has made some efforts to prevent teasing due to the increasing rate of suicide among victims of teasing. It should be noted that the incidence of teasing in many times is unreported, for fear of reprisals and exposure to public shame. Aforementioned is particularly important to understand; women are put under stress by archaic rules concerning so-called chastity and nobility.

The main objective of this paper is to examine to what extent the abuse in teasing against girls affects the human rights in the gender perspective in Bangladesh where 48.5 percent of the population is female.

\section{CONCEPTUAL ISSUES}

Child abuse is behaviour that resulted in damage done to a child, which cannot be reasonably explained, and which is often represented by an injury or series of injuries appearing to be non-accidental in nature. The child is being abused in different perspectives viz. physical abuse, sexual abuse and emotional abuse along with neglect which includes lack of supervision, inappropriate housing or shelter, inadequate provision of food and water, inappropriate clothing for season or weather, abandonment, denial of medical care and inadequate health care facilities.

The concept of teasing is associated with sexual harassment either in public places or elsewhere against girls by boys. Shapiro, Baumeister and Kessier (1991) explained teasing as a personal communication, directed by an agent toward targeted girls. The aggression, humour and ambiguity are the major dimensions of teasing. Alberts (1992) has defined teasing as an aggressive verbalization against targeted girls. According to Eder (1993), teasing is a playful remark aimed at another person, such as mock challenges, commands, and threats as well as imitating and 
exaggerating someone's behaviour in a playful way. While the content of teasing is often negative or hostile, the playful meaning is determined in part by cues from the perpetrators indicating that the remark is a playful manner (Rachel, 2001).

Warm (1997) viewed teasing as a deliberate act designed by the perpetrators to cause tension in the victim, such as anxiety, frustration anger, embarrassment, humiliation, etc., and it is presented in such a way that the victims can escape if they 'catch on'. Infant (1987) distinguished two different teasing; constructive and destructive. In this paper, for example, sexual abuse is teasing against girls, and it is an evil attitude, bullying behaviour and act against the girls by the perpetrators. More specifically, it is an arousing sexual behaviour and tendency to entice into action to achieve the desired goal.

Human rights are typically called natural rights, basic rights or fundamental rights that are inherent in a human being, and without which a person cannot live as a human being (Kapoor, 2003; Ahamuduzzaman, 2006). In many societies girls are devalued as human beings from the day they are born and they are made conscious that unlike their brothers, who are assets to the family, they are liabilities (Sarker, 2010).

Laws are enacted to protect human rights, yet women still deprived of their fundamental rights (United Nations, 1993). The concept of human rights is confined here to the rights of the girls in relation to their education, security and mental health which are very crucial for quality of life and well-being. Teasing against girls is also a violation of the rights of the girls in terms of their free movement, either to school or working place or market or anywhere. It also violets the security of girls and compelled them for dropout from education, encourage for early marriage as well as early pregnancy that ultimately affects the health of the mothers and children.

\section{RESEARCH METHODOLOGY}

Empirical evidences for this paper are from the research project entitled Teasing against Girls and Its Impact on Education in Bangladesh that was conducted in 2011-2012.The author was the principal researcher of the project. 240 girls who 
were respondents of the study were selected using the technique of purposive sampling. The study utilized survey, observation, FGD, use of key informants and case study methods to collect reliable and authentic information on this sensitive subject of the victims. Three districts were selected keeping in view with the objectives of the study.

The selected districts of research were Dhaka, Jessore and Rajshahi. The individual victims of teasing were identified from different areas of three selected districts. Each field investigator was there for a specific period for collection of data. To conduct the survey questionnaire was prepared to keep in view with the objectives of the study. The questionnaire was administered by the

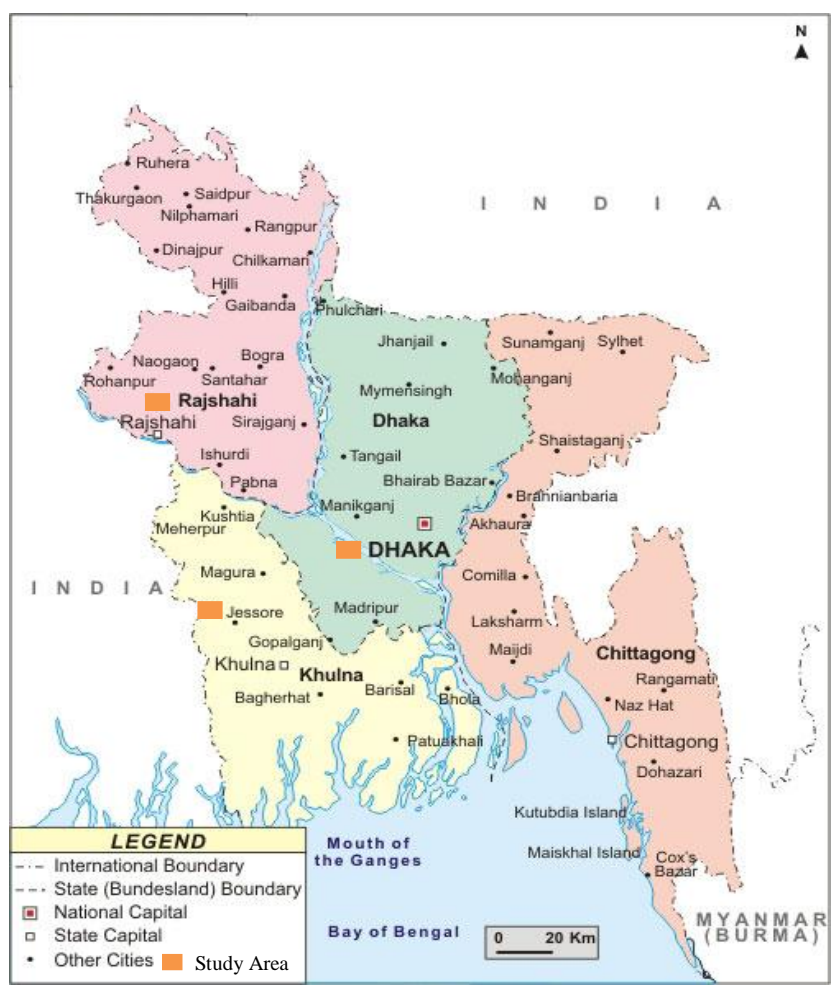
victims of teasing individually.

To collect in-depth information, the study used a case study method. Pseudonym was used against the real name of the individual case. The key informants were selected from a cross-section of people to supplement the survey data. They were the local leaders, school teachers, peer group, law enforcement agencies, neighbours, parents, etc. Both qualitative and quantitative techniques were applied to the analysis of the data. However, the emphasis is on the qualitative technique. 


\section{THE VICTIMS OF TEASING}

This section deals with the age structure and level of education of the girls' who were the victims of teasing by the perpetrators. Age structures referred to the girls' age when they first victimized by perpetrators. On the other hand, level of education referred to the class specification i.e. in what classes the girls were at the time of teasing. Data in Table 1 gives a clear idea about the age structure of the girls along with their level of education.

Table 1: Age structure and level of education of the victims of teasing

\begin{tabular}{|c|c|c|c|c|c|c|c|c|}
\hline \multirow[b]{2}{*}{$\begin{array}{c}\text { Age } \\
\text { Structure }\end{array}$} & \multirow[b]{2}{*}{$\begin{array}{c}\text { Grade } \\
\mathbf{v}\end{array}$} & \multicolumn{6}{|c|}{ Level of Education } & \multirow[b]{2}{*}{ Total } \\
\hline & & $\begin{array}{c}\text { Grade } \\
\text { vi }\end{array}$ & $\begin{array}{c}\text { Grade } \\
\text { vii }\end{array}$ & $\begin{array}{c}\text { Grade } \\
\text { viii }\end{array}$ & $\begin{array}{l}\text { Grade } \\
\text { ix }\end{array}$ & $\underset{x}{\text { Grade }}$ & $\begin{array}{c}\text { Grade } \\
\mathrm{x}+\end{array}$ & \\
\hline $10-12$ & $\begin{array}{c}20 \\
(8.3)\end{array}$ & $\begin{array}{c}15 \\
(6.3)\end{array}$ & o & 0 & $\mathrm{O}$ & $\mathrm{o}$ & o & $\begin{array}{c}35 \\
(14.6)\end{array}$ \\
\hline $12-14$ & o & $\begin{array}{c}15 \\
(6.3)\end{array}$ & $\begin{array}{c}25 \\
(10.4)\end{array}$ & $\begin{array}{c}20 \\
(8.3)\end{array}$ & $\mathrm{O}$ & $\mathrm{o}$ & $\mathrm{o}$ & $\begin{array}{c}60 \\
(25.0)\end{array}$ \\
\hline $14-16$ & 0 & 0 & $\begin{array}{c}15 \\
(6.3)\end{array}$ & $\begin{array}{c}20 \\
(8.3)\end{array}$ & $\begin{array}{c}25 \\
(10.4)\end{array}$ & $\begin{array}{c}26 \\
(10.8)\end{array}$ & 0 & $\begin{array}{c}90 \\
(35.8)\end{array}$ \\
\hline $16-18$ & 0 & $\mathrm{o}$ & $\mathrm{o}$ & $\mathrm{O}$ & 0 & $\begin{array}{c}4 \\
(01.7)\end{array}$ & $\begin{array}{c}30 \\
(12.5)\end{array}$ & $\begin{array}{c}30 \\
(14.2)\end{array}$ \\
\hline $18+$ & 0 & o & o & o & o & o & $\begin{array}{c}25 \\
(10.4)\end{array}$ & $\begin{array}{c}25 \\
(10.4)\end{array}$ \\
\hline Total & $\begin{array}{c}20 \\
(8.3)\end{array}$ & $\begin{array}{c}30 \\
(12.6)\end{array}$ & $\begin{array}{c}40 \\
(16.7)\end{array}$ & $\begin{array}{c}40 \\
(16.6)\end{array}$ & $\begin{array}{c}25 \\
(10.4)\end{array}$ & $\begin{array}{c}30 \\
(12.5)\end{array}$ & $\begin{array}{c}55 \\
(22.9)\end{array}$ & $\begin{array}{c}240 \\
(100.0)\end{array}$ \\
\hline
\end{tabular}

Data in Table 1 show that about 14.6 percent of the respondents were victims of teasing when they were in grade V and V1. It is interesting to note that they had experienced teasing even before reaching their age of puberty. Similarly, about 25 percent respondents were victims of teasing when they were in grade V11 and V111. On the other hand, about 35.8 percent girls were the victims of teasing when they were a student of grade V11, V111, $1 \mathrm{X}$ and $\mathrm{X}$ respectively. Only 10.4 percent students were victims when they were in the age to attend college.

Thirty six percent respondents experienced teasing when their age was 14-16 years, and while they were studying in Grade V11 to X. The second highest victim of 
teasing ( 25 percent) belonged to the age group of 12 to 14 years old. Similar percent of the respondents reported that they encountered the experiences when they were in Grade $\mathrm{X}$ and $\mathrm{X}+$, and they were belonged to the age group of 16 to 18 years old. Only one-third of the victims of teasing experience it when they were in Grade VII and VIII. It is interesting to note that only 10.4 percent of the girls were victims of teasing because they were matured compared to the other students.

\section{CAUSES OF TEASING}

Table 2: Causes of Teasing against Girls by the Perpetrators

\begin{tabular}{|c|c|c|c|c|c|c|c|c|}
\hline \multirow[t]{2}{*}{ Causes of Teasing } & \multicolumn{7}{|c|}{ Level of Education of the Victims } & \multirow[t]{2}{*}{ Total } \\
\hline & $\begin{array}{l}\text { Grade } \\
\text { V }\end{array}$ & $\begin{array}{c}\text { Grade } \\
\text { VI }\end{array}$ & $\begin{array}{c}\text { Grade } \\
\text { VII }\end{array}$ & $\begin{array}{c}\text { Grade } \\
\text { VIII }\end{array}$ & $\begin{array}{l}\text { Grade } \\
\text { IX }\end{array}$ & $\begin{array}{l}\text { Grade } \\
\text { X }\end{array}$ & $\begin{array}{c}\text { Grade } \\
\mathrm{X}+\end{array}$ & \\
\hline $\begin{array}{c}\text { Ineffective Law and } \\
\text { Order }\end{array}$ & $\begin{array}{c}15 \\
(6.3)\end{array}$ & $\begin{array}{c}10 \\
(4.2)\end{array}$ & o & o & o & $\mathrm{o}$ & o & $\begin{array}{c}25 \\
(10.5)\end{array}$ \\
\hline $\begin{array}{c}\text { Lack of } \\
\text { Socialization }\end{array}$ & o & $\begin{array}{l}15 \\
(6.3)\end{array}$ & $\begin{array}{c}20 \\
(8.4)\end{array}$ & $\begin{array}{c}20 \\
(8.4)\end{array}$ & $\mathrm{o}$ & o & o & $\begin{array}{c}55 \\
(23.1)\end{array}$ \\
\hline $\begin{array}{l}\text { Did not Protest } \\
\text { against the } \\
\text { Perpetrators }\end{array}$ & o & $\mathrm{o}$ & $\begin{array}{l}15 \\
(6.3)\end{array}$ & $\begin{array}{c}17 \\
(7.0)\end{array}$ & $\begin{array}{c}21 \\
(8.7)\end{array}$ & $\begin{array}{c}18 \\
(7.5)\end{array}$ & o & $\begin{array}{c}71 \\
(29.7)\end{array}$ \\
\hline Patriarchal Society & o & o & o & $\mathrm{o}$ & o & $\begin{array}{c}4 \\
(1.6)\end{array}$ & $\begin{array}{c}22 \\
(9.1)\end{array}$ & $\begin{array}{c}26 \\
(10.9)\end{array}$ \\
\hline $\begin{array}{l}\text { Political Power } \\
\text { Practice }\end{array}$ & $\begin{array}{c}2 \\
(0.8)\end{array}$ & $\begin{array}{c}5 \\
(2.0)\end{array}$ & o & $\mathrm{o}$ & $\mathrm{o}$ & $\begin{array}{c}6 \\
(2.6)\end{array}$ & $\begin{array}{c}25 \\
(10.4)\end{array}$ & $\begin{array}{c}38 \\
(15.9)\end{array}$ \\
\hline Recreation & o & $\mathrm{o}$ & o & o & $\begin{array}{c}4 \\
(1.7)\end{array}$ & o & $\mathrm{o}$ & $\begin{array}{c}4 \\
(1.7)\end{array}$ \\
\hline $\begin{array}{c}\text { Wearing } \\
\text { Unconventional } \\
\text { Dress }\end{array}$ & o & o & o & $\begin{array}{c}3 \\
(1.3)\end{array}$ & $\mathrm{o}$ & o & $\begin{array}{c}8 \\
(3.3)\end{array}$ & $\begin{array}{c}11 \\
(4.6)\end{array}$ \\
\hline $\begin{array}{l}\text { Pressure of Peer } \\
\text { Group }\end{array}$ & $\begin{array}{c}3 \\
(1.3)\end{array}$ & o & $\begin{array}{c}5 \\
(2.0)\end{array}$ & $\mathrm{o}$ & o & $\begin{array}{c}2 \\
(0.8)\end{array}$ & $\mathrm{o}$ & $\begin{array}{c}10 \\
(4.2)\end{array}$ \\
\hline Total & $\begin{array}{c}20 \\
(8.4)\end{array}$ & $\begin{array}{c}30 \\
(12.5)\end{array}$ & $\begin{array}{c}40 \\
(16.7)\end{array}$ & $\begin{array}{c}40 \\
(16.7)\end{array}$ & $\begin{array}{c}25 \\
(10.4)\end{array}$ & $\begin{array}{c}30 \\
(12.5)\end{array}$ & $\begin{array}{c}55 \\
(22.8)\end{array}$ & $\begin{array}{c}240 \\
(100.0)\end{array}$ \\
\hline
\end{tabular}

Teasing against girls' is associated with the economic, socio-cultural, political, psychological and geographical factors. It is a product of the economic system, social structure, law and order and culture of the people. From the study, the main victims of teasing are the teenaged girls, and the perpetrators are the teenaged boys and youth. Consequently, teasing is related to emotion. It is also related to economic inequality and socialization of the children at the family level. In order to 
get a clear idea, information in Table 2 display main causes of teasing below in the Table 2.

For causes of teasing, 10.5 percent of the respondents reported that the main reason was ineffective law and order of the country. 23.1 percent reported that lack of proper socialization of the perpetrators contributed to the behaviour. It is interesting to note that they blamed the parents of the perpetrators for their inabilities to provide proper socialization. They believed if the parents properly socialized their children, then the perpetrators could not be involved in this antisocial activity.

On the other hand, 29.7 percent of the girls reported that the main cause of teasing was that the victims did not protest the perpetrators. Many of the girls did not protest because of their social status, and they wanted to get away from them. 10.9 percent of the girls thought that the main cause of teasing was male domination at the individual, family and societal levels and, as a result they tried to adjust with this situation.

About 15.9 percent girls reported that the instinct of political power i.e. fathers of the perpetrators involvement in the state power structure; either directly or indirectly contributed to the teasing. Consequently, the perpetrators do not care to be involved in teasing.

Also, 1.7 percent students reported that young persons do not have any recreational facility, and, "as a result" many of them involved in teasing as recreation. About 4.6 percent of the respondents thought that wearing unconventional dress stimulates the perpetrators to tease. Another 4.2 percent of the girls reported that peer group pressure was one of the reasons of teasing against girls.

\section{TYPES OF TEASING}

In the study, the nature of teasing refers to how the perpetrators tease against girls. The nature of teasing depends on the social and physical environment of where the teasing is taking place. The nature of teasing is grouped into physical teasing and oral 
teasing. It is also include the act of showing gestures and postures by the perpetrators at the time of teasing.

Data in Table 3 gives a clear picture regarding the nature of teasing. During the fieldwork, the researcher observed that sometimes the perpetrators tried to be more aggressive, and showed the victims that they are the subordinate powerless individual. These activities make the perpetrator a heroic and influential among his peer groups.

Table 3: Nature of Teasing against Girls by the Perpetrators

\begin{tabular}{cccccc}
\hline $\begin{array}{c}\text { Age } \\
\text { In Year }\end{array}$ & Physical & Oral & $\begin{array}{c}\text { Nature of Teasing } \\
\text { Showing } \\
\text { Gesture \& } \\
\text { posture }\end{array}$ & Others & Total \\
\hline $10-12$ & 10 & 13 & 7 & 5 & 35 \\
& $(4.2)$ & $(5.4)$ & $(2.9)$ & $(2.0)$ & $(14.5)$ \\
$12-14$ & 18 & 12 & 15 & 15 & 60 \\
& $(7.5)$ & $(5.0)$ & $(6.3)$ & $(6.3)$ & $(25.1)$ \\
$14-16$ & 22 & 35 & 23 & 10 & 90 \\
& $(9.2)$ & $(14.6)$ & $(9.6)$ & $(4.2)$ & $(37.6)$ \\
$16-18$ & 8 & 15 & 6 & 1 & 30 \\
& $(3.3)$ & $(6.3)$ & $(2.5)$ & $(0.4)$ & $(12.5)$ \\
$18+$ & 6 & 11 & 5 & 3 & 25 \\
& $(2.5)$ & $(4.6)$ & $(2.0)$ & $(1.25)$ & $(10.35)$ \\
Total & 64 & 86 & 56 & 34 & 240 \\
& $(26.7)$ & $(35.9)$ & $(23.3)$ & $(14.6)$ & $(100.05)$ \\
\hline
\end{tabular}

Data in Table 3 shows that 26.7 percent of the respondents reported that they were physically teased. Physical teasing includes holding the hand in an aggressive and forceful manner, touch the girl's body, thrown stone and solid soil, and grab the girls' clothes. On the other hand, 35.9 percent of the respondents reported that they were orally harassed; such as filthy proposal related to sex, bawdy proposal for marriage and to make friend, addressed with the obscene words, etc. About 23.3 percent of the girls reported that the perpetrators showing gesture and posture of the body to them. 14.6 percent of the girls mentioned that the perpetrators showed and/or threw condoms at them. 


\section{PROCESS OF TEASING}

The process of teasing refers to the way in which the perpetrators teased the girls. It covers the place where the teasing occurs, relationship between the girls and the perpetrators and the way in which the perpetrators tease the girls. Teasing can occur in many ways such as verbal teasing that includes bullying, using vulgar or filthy words, and giving bad comments on the physical structure of the targeted. From the FGD data, the researcher identified different ways of teasing against girls. Among them were using the eyes, trying to touch, pulling clothes, making barrier on their walkway, throwing different odd sounds, throwing objects, bullying, throwing rebuke related to sex, passing physical structure related comments, throwing flowers, taking pictures through mobile phone, gathering in front of girls schools, shouting, laughing behind, singing songs, throwing letters, physical harassment, throwing flying kiss, giving threat, etc.

\section{PLACE OF TEASING}

In the context of the study, the place of teasing against girls is used to refer to physical space or convenient spot of where the teasing taking place. The behaviour took place either in the private or public spheres. It happens when the victims were in their own residences, beside the road, recreation centre, shopping mall, on the public transport, and in the campus of the education institution i.e. school.

Table 4: Place of Teasing against Girls by the Perpetrators

\begin{tabular}{cccccccc}
\hline $\begin{array}{c}\text { Age in } \\
\text { Year }\end{array}$ & House & Road & $\begin{array}{c}\text { Place of Teasing } \\
\text { Recreation } \\
\text { Centre }\end{array}$ & $\begin{array}{c}\text { Shopping } \\
\text { Mall }\end{array}$ & Transport & School & Total \\
\hline \multirow{2}{*}{$10-12$} & 15 & 5 & 5 & 1 & 4 & 5 & 35 \\
& $(6.3)$ & $(2.0)$ & $(2.0)$ & $(0.4)$ & $(1.6)$ & $(2.0)$ & $(14.3)$ \\
$12-14$ & 10 & 21 & 5 & 10 & 10 & 4 & 60 \\
& $(4.2)$ & $(8.8)$ & $(2.0)$ & $(4.2)$ & $(4.2)$ & $(1.6)$ & $(25.0)$ \\
$14-16$ & 12 & 20 & 11 & 10 & 22 & 15 & 90 \\
& $(5.0)$ & $(8.3)$ & $(4.6)$ & $(4.2)$ & $(9.2)$ & $(6.3)$ & $(37.6)$ \\
$16-18$ & 3 & 11 & 4 & 4 & 6 & 2 & 30 \\
& $(1.3)$ & $(4.6)$ & $(1.6)$ & $(1.6)$ & $(2.5)$ & $(0.9)$ & $(12.6)$ \\
$18+$ & 2 & 8 & 8 & 4 & 3 & 0 & 25 \\
& $(0.9)$ & $(3.4)$ & $(3.4)$ & $(1.6)$ & $(1.3)$ & & $(10.5)$ \\
Total & 42 & 65 & 33 & 29 & 45 & 26 & 240 \\
& $(17.7)$ & $(27.1)$ & $(13.6)$ & $(12.0)$ & $(18.8)$ & $(10.8)$ & $(100.0)$ \\
\hline
\end{tabular}


Seventeen point seven (17.7) percent of the respondents reported that they experienced the teasing at their natal residence. Under the circumstances, the perpetrators were the invited guests and relatives. 27.1 percent victims reported that they are the subject of teasing beside the road when they were walking to go somewhere.

On the other hand, 13.6 percent were the victims of teasing at the recreational centres viz. park, cinema hall, and play ground when they were watching outdoor games like football; cricket etc. 12 percent girls were teased at the shopping mall. Similarly, 18.8 percent girls and 10.8 percent girls encountered the problem when they were on the public transport, and while were in the vicinity of their education institutions.

\section{RELATIONSHIP WITH THE PERPETRATORS}

This section deals with the relationship between the girls and the perpetrators in relation to teasing. Three types of relationships appear; affine, consanguine and fictive. The affine relation takes place through marital tie. On the other hand, fictive relationship is established through social contact like neighbour, friend, etc.

Table 5: Relationship between the Victims of Teasing and the Perpetrators

\begin{tabular}{ccccccc}
\hline Age & Relatives & Neighbours & Friend & $\begin{array}{c}\text { Unknown } \\
\text { Person }\end{array}$ & Others & Total \\
\hline \multirow{2}{*}{$10-12$} & 10 & 8 & 5 & 7 & 5 & 35 \\
& $(4.2)$ & $(3.3)$ & $(2.0)$ & $(2.9)$ & $(2.0)$ & $(14.4)$ \\
$12-14$ & 15 & 12 & 10 & 15 & 8 & 60 \\
& $(6.3)$ & $(5.0)$ & $(4.16)$ & $(6.3)$ & $(3.3)$ & $(25.0)$ \\
$14-16$ & 12 & 15 & 20 & 30 & 13 & 90 \\
$16-18$ & $(5.0)$ & $(6.3)$ & $(8.3)$ & $(12.5)$ & $(5.4)$ & $(37.5)$ \\
& 3 & 5 & 8 & 10 & 4 & 30 \\
$18+$ & 1 & $(1.3)$ & $(3.3)$ & $(4.2)$ & $(1.7)$ & $(12.5)$ \\
& $(0.4)$ & $(2.5)$ & $(2.0)$ & $(4.6)$ & $(0.9)$ & $(10.4)$ \\
Total & 41 & 46 & 48 & 73 & 32 & 240 \\
& $(17.2)$ & $(19.1)$ & $(19.8)$ & $(30.5)$ & $(13.3)$ & $(100.00)$ \\
\hline
\end{tabular}


Data in Table 5 shows that 17.2 percent victims reported that they had consanguine or affine or fictive relationships with the perpetrators. On the other hand, 19.1 percent victims reported that they had fictive kin relationship with the perpetrators. 19.8 percent reported that the perpetrators were their friends.

To quote Abida:

I am 17 years old Abida and a student of grade $x$ of Halima Khatun Girls High School. I was a victim of teasing by my brother's wife's Brother (Br.Wi.Br.). His name is Abdur Rahman. We had good relationship before teasing as our close relative. We had also joking relationship to make fun. The perpetrator was a student of B M. College, Barishal. Once he proposed me to be more closed with him. I could not understand the meaning of this sentence. I informed my mother that Rahman proposed me to be more closed and could not understand. My mother suggested me to keep away from him. She also told me that he was not a good boy. According our relationship was fade away as it was before. Rahman could realize that I did not like him. Eventually, Rahman and his friend teased me throwing insulting words when I was going to my school by rickshaw. I felt very bad and as a result I could able give proper attention to my classes.

Again I informed my mother in details and she became astonished and informed my father regarding this issue. My father also informed my brother and sister in law that Rahman was doing very bad thing and he should come to our house further. My brother and sister in law communicated with Rahman and he denied that he did not tease me on the way to school. Even he told them that he did not meet me for a long time. My brother and sister in law become dissatisfied upon me. The relationship between my parents and bothers and his wife has declined regarding issue and as a result my brother and his wife showed their interest to be separated from them. Ultimately, they formed their nuclear family and were living in the same house. Just they led their independent economic life. My parents were shocked, because my brother was earning member of the family. Due to financial constrained, I had to stop my education and got marriage with a business man at the same town.

\section{IMPACTS OF TEASING}

Impacts of teasing on human rights were found in terms of education, mental health such as anger, depression, anxiety, lower grades in examination, non-building peers, loneliness, isolation suicidal thoughts and feelings of insecurity among the victims of 
teasing (Veenstra et al., 2005; Nansel et al., 2001; Hawker \& Boulton, 2000; Craig, 1998; Perry et al., 1988). These components of violation of human rights are very much related and interlinked. Hawker and Boulton (2000), for example, found victims of teasing, in particular girls, were less interested on their education, irregular in attending classes, felt insecurity, low performance, discontinue of education, stress and trauma. Teasing is also correlated with low self-esteem, early age at marriage, teen age pregnancy and early motherhood, social status, migration, dowry, and suicide (Klomek et al., 2008).

Table 6: Impact of Teasing on Victims

\begin{tabular}{|c|c|c|c|c|c|c|c|c|}
\hline \multicolumn{9}{|c|}{ Impact of Teasing on Human Rights } \\
\hline $\begin{array}{c}\text { Age } \\
\text { In } \\
\text { Year }\end{array}$ & $\begin{array}{c}\text { Less Interest } \\
\text { on } \\
\text { Education }\end{array}$ & $\begin{array}{l}\text { Irregular } \\
\text { in } \\
\text { attending } \\
\text { classes }\end{array}$ & $\begin{array}{c}\text { Low } \\
\text { performance }\end{array}$ & $\begin{array}{c}\text { Discontinuation } \\
\text { of education }\end{array}$ & $\begin{array}{c}\text { Felt } \\
\text { insecurity }\end{array}$ & $\begin{array}{c}\text { Stress } \\
\text { and } \\
\text { trauma }\end{array}$ & Other & Total \\
\hline $10-12$ & $\begin{array}{c}5 \\
(2.0)\end{array}$ & $\begin{array}{c}4 \\
(1.7)\end{array}$ & $\begin{array}{c}5 \\
(2.0)\end{array}$ & $\begin{array}{c}3 \\
(1.25)\end{array}$ & $\begin{array}{c}4 \\
(1.7)\end{array}$ & $\begin{array}{c}6 \\
(2.5)\end{array}$ & $\begin{array}{c}8 \\
(3.3)\end{array}$ & $\begin{array}{c}35 \\
(14.45)\end{array}$ \\
\hline $12-14$ & $\begin{array}{c}7 \\
(2.9)\end{array}$ & $\begin{array}{c}7 \\
(2.9)\end{array}$ & $\begin{array}{c}2 \\
(0.83)\end{array}$ & $\begin{array}{c}16 \\
(6.7)\end{array}$ & $\begin{array}{c}11 \\
(4.6)\end{array}$ & $\begin{array}{c}11 \\
(4.6)\end{array}$ & $\begin{array}{c}6 \\
(2.5)\end{array}$ & $\begin{array}{c}60 \\
(25.0)\end{array}$ \\
\hline $14-16$ & $\begin{array}{c}10 \\
(4.16)\end{array}$ & $\begin{array}{c}12 \\
(5.0)\end{array}$ & $\begin{array}{c}10 \\
(4.16)\end{array}$ & $\begin{array}{c}13 \\
(5.4)\end{array}$ & $\begin{array}{c}23 \\
(9.6)\end{array}$ & $\begin{array}{c}12 \\
(5.0)\end{array}$ & $\begin{array}{c}10 \\
(4.16)\end{array}$ & $\begin{array}{c}90 \\
(38.0)\end{array}$ \\
\hline $16-18$ & $\begin{array}{c}2 \\
(0.83)\end{array}$ & $\begin{array}{c}7 \\
(2.9)\end{array}$ & $\begin{array}{c}1 \\
(0.41)\end{array}$ & $\begin{array}{c}3 \\
(1.25)\end{array}$ & $\begin{array}{c}9 \\
(3.75)\end{array}$ & $\begin{array}{c}4 \\
(1.7)\end{array}$ & $\begin{array}{c}4 \\
(1.7)\end{array}$ & $\begin{array}{c}30 \\
(12.5)\end{array}$ \\
\hline $18+$ & 0 & $\begin{array}{c}8 \\
(3.3)\end{array}$ & $\begin{array}{c}3 \\
(1.25)\end{array}$ & $\begin{array}{c}4 \\
(1.7)\end{array}$ & $\begin{array}{c}7 \\
(2.9)\end{array}$ & $\begin{array}{c}1 \\
(0.41)\end{array}$ & $\begin{array}{c}2 \\
(0.83)\end{array}$ & $\begin{array}{c}25 \\
(10.4)\end{array}$ \\
\hline Total & $\begin{array}{c}24 \\
(9.9)\end{array}$ & $\begin{array}{c}38 \\
(15.8)\end{array}$ & $\begin{array}{l}21 \\
(8.7)\end{array}$ & $\begin{array}{c}39 \\
(16.3)\end{array}$ & $\begin{array}{c}54 \\
(22.6)\end{array}$ & $\begin{array}{c}34 \\
(14.2)\end{array}$ & $\begin{array}{c}30 \\
(12.5)\end{array}$ & 240 \\
\hline
\end{tabular}

From data in Table 6, 9.9 percent of the respondents reported that they were not interested with their education after the incidence of teasing. 15.8 percent were found irregular in attending their classes. 8.7 percent of them informed that their class room performance and result of the examinations were not satisfactory because they could not able to provide good attention because of stress due to teasing. About 22.6 students reported that they felt insecure especially on the way to school. About 16.3 percent girls reported that they discontinue their education for insecurity and the same time their guardians did not want to send them to school because of teasing by the perpetrators. It is reported that about 14.2 percent students were suffering from 
stress and trauma because they are deprived from the opportunity of education to develop their future career.

To quote a student of grade $\mathrm{X}$ :

My name is Salma. I was a 16 year aged student of grade X of Laxmipur Girls' High school. It was situated nearby Rajshahi Medical College Hospital. I was living in Hetem Khan with my parents along with one younger brother and sister. They were also primary school students. The distance of my school is about one km. It should be noted that most of the time I avail rickshaw. Sometimes I had to walk when rickshaw was not available. One day I could not find rickshaw after the school and as a result I decided to walk and at the middle of my walking distance of my house from school I found that two boys were proposed me to make friendship. I refused them and they again proposed me. Once I was threat them.

After a few weeks again I was walking on the road and they followed and proposed me on the way to my home from school. I told them if you commit the same thing I shall inform to the police. They become aggressive and pulled out my orna (wearing cloth). I could not express my problem to my teachers and parents and as a result I always felt insecurity to walk on the road. Sometime I felt stress and become traumatized after having the experience of teasing. I could get sleep well. Even I could study as it was before. Consequently, I did not well in the last examination.

It is found from the statement of Salma that teasing caused her stress and traumatized, and that affected her education. She felt insecure and live in anxiety which exhibited high rate of stress and depression. Olweus (1978) and Hawker \& Boulton (2000) reported in their studies that most of the victims of teasing were mentally sick and that affected their daily functioning. Consequently, it not only affected the education rights of the girl but also it indirectly affected the employment opportunities, income and their participation in decision making.

Another interesting case study is cited here in order to give readers the real picture of the impact of teasing. This verbatim is from Rahima, and she was a student of grade 1X of Vivekananda Girls School of Cox Bazar.

When I was a student of grade1X of Vivekananda Girls School I was disturbed by a boy on the way to school. This boy was working in a studio which was situated besides the road. I requested several times not to disturb but he did not stop. Finally, I had to inform my parents. My father met the boy with 
a local political leader and he threatened him not to commit same thing against me further. It was stopped for around six month. But after a political change, that boy was started to disturb me again with his friends and they wanted kidnap me. My father was working in the Social Service Department and finally he requested to the Directorate of Social Services for transfer his job from Cox Bazar to Comilla. Ultimately, we migrated to Comilla for my security. I could not get chance for admission there and as result I had to stop out from my education and waiting for marriage according to the decision of my parents. My parents were in anxiety for my future because their dream was for my higher education. I become the mental patient and I lost my confidence on my life and I thought that suicide is the best way to get rid of mental anxiety. One late night I hanged myself with a ceiling fan in my bed room, my parents came to know and they saved me. Finally, my parents arranged marriage for me.

This case indicates that teasing against girls is one of the causes of drop out from their education which not only affects the rights of education but also affects the mental health. It is not only confined to drop out rather it encourages early age at marriage and at the same time early mother hood which affects the maternal and child health. Moreover, it contributes to population explosion, which is one of main social problem in Bangladesh.

Another case is the case of Rasheda. She was a student of grade 1X of Bogra High School and living in Kalitala of Bogra town with her parents and siblings. She encountered the problem in the school premise, and the perpetrator was a student at the same school. But he was a student of grade x. She quitted school after the incident. To quote Rasheda:

My name is Rasheda. I was a student of grade $1 X$ of Bogra High School. My father is a salesman of a cloth store in Bogra town. I was teased by the perpetrator who was a student of this school which is already mentioned. I complained against him several times but the school authority did not able to take proper action because the perpetrator was involved in politics and his father was also involved with power structure of the politics.

My parents arranged my marriage with a local business man provided that I could continue my study. My father had to pay a 
good amount of cash as dowry. After one year of our conjugal life, my husband wanted to get more money as dowry to enhancement his business, but my father refused pay. Under the circumstances, my husband sent me to my natal residence and as a result now I am living with my parents. I always feel insecure to survive regarding my future.

It is clear from this case study that teasing against girls affects the education of the victims. Teasing and drop out is highly correlated and associated with the social structure in which both the victims and perpetrators born, brought up and live. The severe impact, the victims always feel insecure about their life and future.

\section{DISCUSSION AND CONCLUSION}

Teasing against girl is an emerging issue across the East and the West (Charach, Pepler \& Ziegler, 1995). In Anthropological perspective, teasing is rooted at the family level in kinship network system as joking relationship. This joking relationship has been shifted from family to community as well as societal level. Teasing is a word with many meanings; base on kinship tie. In human interactions, teasing comes in two major forms, playful and hurtful. In mild cases, and especially when it is reciprocal, teasing can be viewed as playful and friendly. Sometimes people tease each-other to make joke. This contributes to friendship and social intimacy. It is a part of culture of many societies and it may help for social solidarity as well as community stability.

On the other hand, teasing is often unwelcome in many cultures. When this happen, it takes the form of harassment. Teasing against girls is basically "an insult with a smile". It is a bullying behaviour imposing on girls for enjoyment. Under the circumstances, the girls feel insecure to go outside their home alone. Consequently, parents are afraid to send their daughters to school and working place; which creates impediment not only for girls' education and employment but also for their human rights.

The dimensions of teasing may be different in cultural perspective, but the real connotation is almost same. Teasing is a euphemism used in Bangladesh mainly 
for sexual harassment of the girls as well as women. Teasing against girls is associated with socio-economic conditions and culture in terms of customs, believes and value system in which the perpetrators born, brought up and live. Due to the complexity, the existing rules and regulations against teasing are inadequate and less effective in practice.

Many of teasing victims commit suicide, when it is beyond tolerance. Recovery oriented mental health services is very meagre in Bangladesh. Some of the GOs, NGOs and POs are providing mental health care services through psychotherapy in counselling to reduce stress, trauma and suicide for the victims so that they can lead their normal life at the family, community and societal levels like the other members of the society.

Recently, the government of Bangladesh has made some efforts to prevent teasing against girls due to increasing stress and traumatic patients which leads to increase suicide rate among the victims. It should be noted that the incidence of teasing in many times is unreported, for fear of reprisals and exposure to public shame. One important reason for the unreported case, and this is particularly important to understand, is women are put under stress by archaic rules concerning so called chastity and nobility.

Therefore, long-term solutions are unlikely without fundamental changes in societal attitudes towards female of male dominated society. There should be a joint effort in order to prevent teasing against girls, involving different sectors and the NGOs who are actively working to prevent teasing as well as for the rehabilitation of the victims. It should be kept in mind that the girls and women are daughters or sisters or wives, or mothers or grandmothers of someone and it is our collective responsibility to honour them as human being. It should be mentioned that the women are not liability; rather they are asset if the society able to protect their basic rights as human being in avoiding gender biased attitude through proper care in the different phases of their life cycles. 


\section{REFERENCES}

Ahamuduzzaman, M. (2006). Learning human rights law. Sobujbag, Dhaka: Shams Publications.

Akhter, Zobida (2013). Eve teasing, tears of the girls: Bangladesh Open University towards women empowerment. International Women online Journal of Distance Education. 2 (4), 1-22.

Alberts, J. K. (1992). An inferential/strategic explanation for the social organization of teases. Journal of Language and Social Psychology, 11, 53-177.

Aziz, K.M. A. (1979). Kinship in Bangladesh. Dhaka: International Centre for Diarrhoeal Disease Research, Bangladesh

Bangladesh Bureau of Statistics (BBS). 2009). Statistical Yearbook 2009. Dhaka: Planning Commission, Peoples Republic of Bangladesh.

Charach, A., Pepler, D., \& Ziegler, S. (1995). Bullying at school- A Canadian Perspective: A survey of problems and aggressions for intervention. Education Canada. 35, 12-18.

Craig, W. M. (1998). The relationship among the bullying, victimization, depression, anxiety and aggression in elementary school children. Personality and Individual Differences. 24, 123-130.

Eder, D. (1993). 'Go get ya a French': Romantic and sexual teasing among adolescent girls. In: D. Tannen (Ed.), Gender and conventional interaction: Oxford studies in sociolinguistics (pp. 17-31). New York: Oxford University Press.

Fledman E., \& Dodge, K. A. (1987). Social information processing and sociometric status: Age sex and situational effects. Journal of Abnormal Child Psychology. 32, 211-227.

Hawker, D. S. J., \& Boulton, M. J. (2000). Twenty years research on peer victimization and psychosocial maladjustment: Meta-analytic review of crosssectional studies. Journal of Child Psychology and Psychiatry. 41(4), 441-455.

Infant, (1987). Aggressiveness. In J. C. Daly (Ed.), Personality and Interpersonal Communication (pp. 44-49). Newbury Oark, CA: Sage.

Kapoor, S. K., (2003). International law and human rights. Allahabad: Central Law Agency.

Klomek, A. B., Sourander, A., Piha, J., Tamminen, T., \& Moilanen, I. (2008). Childhood bullying as a risk for later depression and suicidal ideation among Finish males. Journal of Affective Disorder. 109(1-2), 47-55 
Nansel, T. R., Overpeck, M., Pilla, R.S., Ruan,W.J., Simons-Morton, B., \& Scheldt, P. (2001). Bullying behavior among the US youth: Prevalence and association with psychological adjustment. Journal of the Medical Association. 285, 2094-2100.

Nicolas, R.W. (1961). Economic of family types in two West Bengal villages. The Economic Weekly. XI1 (27), 85-92.

Olweus, D. (1978). Aggression in schools: Bullies and whipping boys. Oxford, England: Hemisphere

Pawluk, C. J. (1989). Social construction of teasing. Journal for the Theory of Social Behavior. 19, 145-167.

Rachel L. DiCioccio. (2001). The development and validation of the teasing communication scale. Human Communication, Pacific and Asian Communication Association. 11(3), 255-272.

Sarker, P. C. (2010). Women in patriarchal society. New Delhi: Serials Publications.

Shapiro, J. P., Baumeister, R. F., \& Kessier, J. W. (1991). A three component model of children's teasing: aggression, humor and ambiguity. Journal of Social and Clinical Psychology. 10, 459-472.

United Nations (1993). Human rights and the girl child. Vienna: United Nations.

Veenstra, R., Lidenberg, S., Oldehinkel, A. J., De Winter, A. F., Verhulst, F. C., \& Ormel, J., (2005). Bullying and victimization in elementary schools: A comparison of bullies, victims, bully/victims, and uninvolved preadolescents. Developmental Psychology. 41, 672-642.

Warm, T. R. (1997). The role of teasing in development and vice-versa. Developmental and Behavioral Pediatrics. 18, 97-101. 